DOI: https://doi.org/10.46630/phm.12.2020.29

Јелена С. Младеновић ${ }^{1}$

Прегледни рад

Универзитет у Нишу

УДК 821.163.41.09"19"

Филозофски факултет

17. 10. 2020.

Департман за српску и компаративну књижевност

\title{
ПРЕГЛЕД СТАВОВА О ПРИРОДИ КЊИЖЕВНЕ КРИТИКЕ У СРПСКОЈ НАУЦИ О КЬИЖЕВНОСТИ
}

Проблематични статус књижевне критике у оквиру науке о књижевности присутан је готово од момента диференцирања свести о постојању ове посебне научне области која се бави тумачењем и вредновањем књижевних дела. Ово истраживање спровели смо са циљем да систематизујемо део теоријских ставова о природи књижевне критике, које проналазимо у српској науци о књижевности током 20. века. Размишљања о књижевној критици, као и о теоријском дискурсу у књижевнокритичким есејима, разматраћемо преко метакритичких ставова присутних најпре у канонским текстовима класика српске књижевне критике - Љубомира Недића, Богдана Поповића и Јована Скерлића, а потом и код низа филолога који су стварали током 20. века - Бранка Лазаревића, Исидоре Секулић, Милана Богдановића, Зорана Мишића, Драгана М. Јеремића, Петра Џаџића, Предрага Палавестре и других. Управо због своје хетерогене природе, а имајући у виду поделу на академску и текућу критику, у прегледу ставова о природи књижевне критике уочавамо да код критичара постоји стална потреба за њеним поновним дефинисањем и одређивањем њене улоге у оквиру науке о књижевности, као и њеног односа према књижевности, кроз читав 20. век до данашњег дана.

Кључне речи: књижевна критика, метакритика, академска критика, дневна критика, српска филологија

\section{1. Уводна разматрања и циљеви истраживања}

Књижевна критика и данас представља подручје науке о књижевности са најпроблематичнијим статусом. Будући да подразумева интер-

\footnotetext{
1. jelena.mladenovic@filfak.ni.ac.rs

${ }^{2}$ Рад представља резултат истраживања на пројекту Истраживања књижевне прошлости и садашъости на простору југоисточне Србије Филозофског факултета Универзитета у Нишу.
} 
претацију и вредновање књижевних дела, критика у најширем смислу, уз академску, обухвата и дневну критику. ${ }^{3}$ Поред појављивања у научним, ње има и у књижевно-научним часописима (који објављују како уметничке, тако и научне текстове), као и у дневним листовима, где је поред научника могу писати и филолози/хуманисти без научних претензија, али и сами писци или поштоваоци лепе књижевности. Баш зато што је реч о хетерогеном подручју које не мора у целости припадати научном дискурсу, књижевни критичари често имају потребе да говоре о њеном положају у оквиру науке о књижевности, као и о односу према лепој књижевности, уз издвајање различитих видова критике.

Главни подстицај за ово истраживање и јесте кренуо из самих текстова српске филологије, односно науке о књижевности, где се од почетка 20. века, од успостављања наше модерне науке о књижевности и заснивања унутрашњег присутпа у проучавању текстова, проблематизовало питање природе књижевне критике, њених циљева и научних домета. Да би протумачила тоталитет књижевног дела, критика се отвара ка различитим методолошким интерпретативним могућностима, али се проблем субјективности, упркос томе што би сваки за науку релевантни интерпретативни чин требало да има утемељење у одређеној теоријској поставци, издвајао као разлог за преиспитивање њеног места у оквиру науке о књижевности. Уочавање метакритичког дискурса у различитим текстовима о којима ће бити речи, нагони на хронолошко проматрање развитка самог појма књижевне критике, односно ка својеврсној компарацији тих виђења и ка запажању сродности/разлика одређених идејних постулата.

Циљ овог прегледа је да укаже на перманентност покушаја давања одоговора на питања о природи и функцији књижевне критике кроз цео 20. и две деценије 21. века. Настојимо да скренемо пажњу на велику индикативност понављања овакве врсте упитаности, која често може бити повезана са тиме што подручју књижевне критике у најширем смислу, како смо то већ поменули, могу припадати и текстови које пишу само љубитељи литературе и пасионирани читаоци са недостатком формалног образовања из области филологије.

\footnotetext{
3 Под књижевном критиком Антоан Компањон подразумева ону врсту дискурса о књижевним делима који наглашава искуство читања, описује, тумачи, процењује смисао и дејство дела на читаоце, не нужно научнике и стручњаке. Компањон има у виду сам чин рецепције који деле професионални и обични читаоци. Говорећи о књижевној историји, с друге стране, издваја чиниоце који су изван искуства читања, на пример концепцију или преношење дела, као и друге елементе незанимљиве лаику (2001: 20). Упозорава и на то колико је сам појам књижевне критике проблематичан будући да се употребљава у општем и посебном смислу - истовремено, он означава „све књижевно проучавање и искуство суђења (2001: 260), али указује и на потребу приближавања историје и критике, које се морају развијати у садејству, водећи рачуна о међусобној разлици (2001: 262).
} 


\section{2. Књижевна критика и метакритика}

„Критика је прва модерна књижевна врста која у нову српску књижевност није дошла са закашњењем, него се у њој јавила и развијала упоредо са развитком у другим већим и срећнијим књижевностима, у истом синхроничном кругу са општим развојем њене форме и значења, у пуном симултанитету и по истим начелима и фазама једног општег књижевноисторијског процеса." (PALAVESTRA 2008: 8-9). Кроз читав развој наше модерне теоријске мисли о књижевности, од самог краја 19. века и заснивања унутрашњег приступа у проучавању књижевности у радовима Љубомира Недића, па све до данас, филолози понаособ покушавају да дефинишу књижевну критику и одреде њено место у оквиру науке о књижевности. Нарочито после педесетих година, критика постаје предмет сопственог проучавања, ауторефлексије, више него у ранијим епохама:

„Метакритика ${ }^{4}$ представља засебан сегмент књижевне критике у српској књижевности друге половине 20. века. Готово да нема значајнијег критичара који није настојао да критички осветли књижевни жанр којим се бави, да медитира (често и ламентира) о значају и улози посла којима се бави, односно да разуме природу и смисао књижевне критике и њену функцију у култури. Неки су изградили целовите теорије књижевне критике (Зоран Гавриловић, Светозар Петровић, Предраг Палавестра, Сретен Марић), други су написали пролегомене за теорију критике, трећи су експлицитно изложили своје критичке поетике, односно своја вјерују." (RADULOVIĆ 2013: 457)

Најобимније систематско проучавање и објављивање српске књижевне критике је остварено на на пројекту Института за књижевност и уметност, у оквиру којег је штампано 25 књига библиотеке Српска књижевна критика (Историја српске књижевне критике од почетака до модерног доба). Сама едиција покушала је дати одговор на питање шта све може бити обухваћено појмом српске књижевне критике, те је у том смислу требало најпре одговорити шта је критика и утврдити њене ка-

\footnotetext{
${ }^{4}$ Метаритика испитује логику интерпретативних и вредносних судова (IGLTON 1987: 138). Под појмом метакритике овде управо имамо у виду теорију књижевне критике, односно теоријске покушаје да се „преосмисли и контекстуализује књижевнокритичка пракса" (PERIŠIĆ 2014: 7). Систематизујући ставове у науци, Игор Перишић упућује на двојаку могућност употребе термина метакритика: у ширем смислу, то је модерније име теорије књижевности (критика у англоамеричком смислу), односно оне теорија која је превредновала свој дисциплинарни статус у односу према другим хуманистичким дисциплинама и заправо постала интердисциплинарна (2014: 37), док је у ужем смислу то ознака за оне текстове који у себи имају метакритички слој на начин књижевне теорије или теоријске прозе.
} 
рактериситке као посебне форме. Испитан је и однос критике према владајућим идејама и идеологијама културе појединих историјских и књижевних епоха. Назначене су морфолошке и типолошке промене критике, измене поступка и развоја књижевних вредности, разјашњене су њене етичке и естетичке основе, главне етапе у развоју, а све то је сагледано и у ширем друштвеном контексту.

Овом приликом се не можемо задржати на свим текстовима који садрже метакритичке осврте о природи књижевне критике, будући да је реч о веома продуктивном периоду и богатом корпусу, на шта указује и двотомна Палавестрина Историја српске кьижевне критике (2008) рађена по принципу поделе на периоде и ауторе, а која обухвата нешто шири период од оног који нас овде интересује (1768-2007). Зато смо одабрали да се задржимо на оним текстовима, односно деловима текстова из програма курса Српска къижевност 20. века - критика и драма, који се према акредитацији ОАС србистике из 2008. године изучавао на Филозофском факултету Универзитета у Нишу. Бавећи се овим канонским текстовима имамо у виду управо оне идеје које ће имати најснажнији утицај на потоњи низ генерација филолога.

Проблем са књижевном критиком почиње још од самог термина. Кровни термин - наука о књижевности - који постоји у нашој филологији, рецимо, не постоји у енглеском језику (за разлику од немачког и руског), те англосаксонско говорно подручје за овај појам користи термин критика. Врло често се, дакле, појам критике јавља као општи појам под који се подводе све области проучавања или писања поводом књижевности (PERIŠIĆ 2014: 21). Веома симплификована дистинкција између теорије, историје и књижевне критике, лако се и у нашој науци о књижевности доводила у питање. Наиме, може се уочити суспектност истраживача према постављању књижевне критике у област науке о књижевности, о чему сведоче и речи Светозара Петровића који науком у правом смислу те речи означава још једино теорију књижевности: „Књижевна критика, закључили смо, није наука, и неће то постати.” (2009: 121)

Издвајање појма текуће, односно дневне критике, и њено позиционирање у односу на критику уопште, враћа нас поменутој подели на две врсте књижевнокритичког дискурса. Са једне стране треба издвојити дневну критику која прати и вреднује, од оне друге, академске, која подразумева присуство методолошких принципа на основу којих се дело интерпретира, али која се углавном бави већ канонизованим литерарним корпусом. Игор Перишић предлаже да ову врсту критике означимо као естетичку или књижевнотеоријску уместо као академску $(2013: 165,166)$. Притом он предлаже поделу књижевне критике на: теоријску као критику која није импресионистичка (заснована на неким научним начелима 
и методологији), естетичку која залеђе има у естетици као филозофској дисциплини и књижевнотеоријску која настаје на књижевној теорији као књижевној естетици, односно естетици суженој на област књижевности (2013: 171-172).

За наше истраживање битно је шта Михајло Пантић, на врло једноставан и прегледан начин, говори о употреби појма књижевне критике у нашој филологији. Он је у различитим традицијама добијао другачија значења и креће се између англосаксонског схватања критике као целокупне мисли о књижевности и германског схватања у којем је појам сужен на означавање дневне критике. „Осећање и употреба тог термина на нашим просторима негде је између тих крајности”. (1984: 133) Појам критике не захвата области теорије и историје књижевности, мада их у много чему додирује. Веома је битно да књижевни критичар не искључује књижевног историчара, нити да овај други у својим истраживањима заобилази књижевну теорију (1984: 133). Област књижевне критике обухвата и означава читав низ критичких жанрова установљених на другачијим основама од дневне критике: критичку прозу, есеј, нацрте, анализе, студије и остале, углавном, хибридне форме. У оваквој хетерогеној структури књижевна критика обитава и данас.

Управо поменута хетерогеност текстова који данас припадају области књижевне критике, за нас је индикатор константног понављања питања о њеној природи и функцији, али и видовима у којима се појављује. Одатле и полази велики проблем у одређењу самог појма, његовом односу према науци и уметности, а што ћемо уочити у прегледу ставова кроз један век развоја српске филологије.

\section{3. Преглед ставова о природи књижевне критике у српској филологији}

Сачинићемо кратак преглед метакритичких ставова наших истраживача на пољу науке о књижевности. Битно је на почетку уочити да се експлицитни ставови истраживача често могу разликовати од самих резултата критичких врденовања и принципа које су директно примењивали у појединачним огледима.

Зачетник унутрашњег приступа у проучавању књижевности код нас, као и саме естетичке критике ${ }^{5}$, Љубомир Недић, сматра да је у ње-

\footnotetext{
${ }_{5}^{5}$ Разматрање појма вредности код Недића може се читати упоредо са појмом вредности код Мукаржовског (1987). Недић донекле антиципира идеје Мукаржовског о универзално важећој вредности у развоју уметности, из текста „Може ли естетска вредност у уметности имати универзално важење” објављеног 1937. године. Када је реч о књижевној критици, проблем субјективности води нас питању укуса, односно естетских вредности
} 
гово доба, крајем 19. и почетком 20. века, критика заостала у односу на књижевну продукцију. У тексту „Новија српска лирика и њени критичари" он резимира постојеће облике критике које сматра превазиђеним - тзв. критику коњичких скокова Светислава Вуловића која од реконструисаних података из песама саставља живот песника, потом импресионистичку критику Светислава Вуловића, односно тзв. политичку критику где се књижевности суди на основу приватне пишчеве личности, и на крају тзв. реалну критику Светозара Марковића, која се једина бави књижевним делима, али искључиво питањима садржине, не и форме, и представља вид утилитарне критике (1977: 69-77). У тексту насловљеном „О књижевној критици” издваја три типа критике: дневну (текућу), потом ону која расправља општа питања, где Недић заправо описује оно што данас сматрамо теоријом књижевности, па можемо рећи да појам критке употребљава у оном смислу у којем се он данас користи на англосаксонском језичком подручју, и на крају критику која проучава (1977: 226-241). Занимљиво је да и поред увиђања неопходности повезивања књижевне критике и историје књижевности, Недић књижевну критику сматра делом уметности, граном књижевности, односно књижевношћу самом, ценећи посебно баш ту критику која није усмерена искључиво на вредновање, већ управо на тумачење дела.

Богдан Поповић продубљује унутрашњи приступ у проучавању књижевности, те тако и појам естетичке критике. Притом је сам колебљив када су њени принципи у питању: на средини је између две крајности од којих једна каже да су естетички принципи непроменљиви, а друга да не може бити никаквих правила за уметничко стварање. Иако је наставио Недићеве идеје о значају емоционалности у рецепцији књижевноуметничког дела, Поповић није успео да оствари естетичку теорију засновану на емоцијама које дело изазива и која га пре свега тумачи па тек онда вреднује, али је у својим разматрањима о природи књижевне критике био веома јасан. Он је против историјске критике где је књижевно дело само документ одређене епохе и заступа естетичку и стилистичку критику зато што она захтева непристрасност критичара. Иако остаје упамћен као један од наших водећих теоретичара књижевност с почетка 20. века, Поповић науку о књижевности најчешће сагледава кроз однос историје књижевности и књижевне критике. Проблем књижевне критике види баш у томе што књижевнокритички посао ради много званих, још више незваних, а мало изабраних (1977: 59). Како Поповић каже, нама је потребна тзв. паметна критика (1977: 59), али би ваљало када би она имала неки знак по којем бисмо је могли распознавати. Грешка је што се њоме баве новинари, те се отуда Поповић посебно залагао за педагошки метод

једног књижевног дела. 
васпитавања укуса као део системског образовања професионалних критичара ${ }^{6}$. Укус је потребан не само да би се читала лепа књижевност, већ и књижевна критика. Подвукавши ову сличност, он донекле имплицитно критику приближава подручју књижевности, будући да је и за једно и за друго неопходан негован укус (1977: 60), али је за разлику од Недића посматра у оквирима науке о књижевности, те наглашава неопходност професионалног усавршавања за такву делатност.

Један од најутицајнијих критичара с почетка века, Јован Скерлић, определио се за „уништење” естетике и демократизацију уметности”, али никада није постао антиестетичар. У својим импресионистичким критикама оставио је запажене интерпретативне судове, залажући се за неку врсту транспоноване субјективности, односно синтезе спољашњег и унутрашњег приступа у тумачењу. Скерлић прави разлику између догматичке и импресионистичке критике, дајући замерке и једној и другој (2000: 13-22). Критика је за њега превасходно чин суђења, између науке и уметности. Догматичка верује у унапред задати идеал лепог као универзални $^{8}$, док импресионистичка такође има теорију, али прикривену, и занемарује социјалну страну уметности. Импресионистичка критика је за Скерлића свакако боља од догматичке, будући да признаје ту немоћ да се да̂ непроменљиво решење.

Павле Поповић ${ }^{9}$, историчар старе књижевности, сматра се и утемељивачем модерне историјске критике код нас. Заступао је идеју одустајања од искључиво филолошког метода у тумачењу књижевности и истицао да је највећа мана наше критике што није организована. Критика треба да оцењује, тумачи и објашњава, указује на књижевни развитак, да утиче на укус, да одражава однос прошлости и савремености, да буде отпорна и независна. Универзитетску историјску критику строго је одвајао од дневне и импресионистичке. Иако је првој замерао спорост, залагао се против дневне критке. Оно што Поповић означава критиком је најближе одређењу науке о књижевности у целини, засноване на историјским принципима. Поред филолошке и критике укуса (литерарни правац), он управо скреће пажњу на историјску критику која је неопходна српској књижевности.

Павле Поповић, Јован Скерлић и Богдан Поповић јасно су се изјашњавали за издвајање академске критике и њено позиционирање у ок-

\footnotetext{
${ }^{6}$ О томе пише у тексту „О васпитању укуса” (POPOVIĆ 1977: 67-93).

${ }^{7}$ Погледати текст „Уништење естетике и демократизација уметности” (SKERLIĆ 2000: 23-43).

${ }^{8}$ Како је то, заправо, само идеал једне епохе, у томе се огледа њена парцијалност, а тиме и мањкавост.

9 Погледати текстове „Критика у српској књижевности”, „Проучавање српске књижевности” и „Стање данашње српске књижевности” (POPOVIĆ 1979).
} 
виру науке о књижевности, те указивали на неопходност посебног образовања за овакав критичарски посао, али нису занемарили чињеницу да постоји и други облик критике, текућа или дневна критика, чији ствараоци нису испуњавали овај предуслов. Таквој академској критици додељивали су место унутар науке о књижевности.

Већ Бранко Лазаревић чини повратак естетичкој, али остаје на подручју импресионистичке критике ${ }^{10}$. Његов панхуманистички естетизам, где је уметност утеха у песмистичкој визији стварности, уводи и појмове естетичког хедонизма и интегралне естетике и опредељује се за тзв. тоталну критику која подразумева принцип интегралности ${ }^{11}$. У тексту „Критички поступак” (1975) и Лазаревић критику посматра као књижевност. Сматра да она није никакав посредник између уметника и публике, и да, иако критичар обрађује грађу која је већ обрађена, она за њега остаје оригинална. Критика је исто што и било које друго уметничко стваралаштво за које је потребан таленат, јер је она у својим циљевима стварање, а само у својим поводима суђење. Лазаревић се, као што ће то у другој половини 20. века учинити Петар Џаџић и Драган М. Јеремић, бавити и критичаревом личношћу. Критичар тако мора бити спонтан и свестран, прилагодљив, слободан и плуралиста. У овом плурализму се види интенција ка каснијем инсистирању на методолошком плурализму у тумачењу књижевног дела. Сматра да су слаби критичари и слаби писци унели забуну у погрешно разумевање инфериорног положаја критичара у односу на писца, јер само велики критичар може бити велики уметник.

Исидора Секулић, за коју се често каже да није имала јединствен критичарски метод, указивала је на значај критике и независно од књижевних дела ${ }^{12}$. Она посебно инсистира на разликовању аутентичне од неаутентичне критике, сматрајући прву веома важном, али сагледавајући је само као самосталну грану књижевности. Аутентична критика заснована је на интерпретацији, а не на пукој анализи ${ }^{13}$. Уметнички књижевни идеал се мора налазити у аутентичном критичару, а дневна критка која је спољна, механичка и брза, не може бити аутентична јер се често бави више писцима него делима. За дневну критику каже да је пишу критичари осионих навика и површног читалачког познавања књижевности.

\footnotetext{
${ }^{10}$ У обзир смо узели његове радове „Стваралачка критика” (LAZAREVIĆ 1975: 325-348) и „Критички поступак” (LAZAREVIĆ 1975: 349-375).

${ }^{11}$ Негде се наслућује и концепт тоталне уметност и антиципира мултимедијалност.

12 Погледати њене есеје „Проблем критике и критичарских талената” (SEKULIĆ 1977: 84-89) и „Критка из дана у дан” (SEKULIĆ 1977: 90-96).

${ }^{13}$ Секулић прави разлику између анализе и интерпретације. Док анализа зависи само од науке и савременог укуса, интерпретација зависи од талента критичара као уметника и писца.
} 
Они је доживљавају као лични тријумф, не размишљајући о делу које је инспирисало њен настанак.

Милан Богдановић (1979: 27-36) такође остаје на путу афирмације импресионистичке критике, тврдећи да она значај постиже онога тренутка када престаје да буде пуко оцењивање. Њега, заправо, теорија критике није много интересовала, иако је говорио о њеној природи. Критичар постаје стваралац када пређе уске границе чистог критиковања. Упозоравајући на то да је прошло време великих критичарских ауторитета, Богдановић сматра да је критика на лошем гласу баш зато што је више побијала, а мање афирмисала ${ }^{14}$. Критичар треба да се клони педантерије, а да се све више труди да буде добар стваралац и зато он мора имати неограничено животно осећање. Богдановић уопште не говори о формалном образовању критичара нити критику посматра као део науке у ужем смислу те речи.

Бранко Лазаревић, Исидора Секулић и Милан Богдановић, више су на трагу ранијих Недићевих размишљања о природи критике ван подручја науке, него што остају поборници афирмације академске критике школованих критичара какви су били Богдан Поповић, Павле Поповић и јован Скерлић.

И у другој половини 20. века проблем одређења књижевне критике и њеног места између науке и уметности не јењава. Зоран Мишић се у тексту „Песничко и критичарско искуство”"15 (1976) бави посебно понором између критике и писаца. Он као да имплицитно осуђује оно схематично тумачење књижевности које је могло настати под утицајем структуралистичких и формалистичких истраживања. Наиме, Мишић каже да се права поезија никада неће отворити критичару (већ читаоцу) и да му никада неће дати алат у руке који би му помогао да је „вивисекцира”. Имплицитно скреће пажњу и на методолошки плурализам у проучавању књижевности, али и на склоности критичара да се определе за један метод у тумачењу и њега држе не би ли се ослободили импресионистичког писања. Међутим, као главну карактеристику тог плурализма, он издваја тзв. методолошку нетрпељивост, док је у запећку остала једина права критика, синтетичка и интегрална. То је критика која не робује једном методу како би се ослободила импресионизма. Уместо да се критика приближава поезији, поезија се приближава критици ${ }^{16}$. Мишић ипак велича

${ }^{14} \mathrm{O}$ томе Богдановић говори у тексту под насловом „Писци и критичари”, објављеном 1928. године.

${ }^{15}$ Мишић је овај текст објавио 1956. године.

16 Ово Мишићево запажање може бити интересантно посматрати и у данашњим околностима, када имамо у виду ствараоце који пишу на обе стране, односно који су и критичари и писци уметничке књижевности. Нарочито они писци који имају формално филолошко или шире хуманистичко образовање, у својим уметничким текстовима 
непосредност сазнања, залажући се како за аутентичну поезију тако и за аутентичну критику мимо доктрине. Ти његови ставови казују да је много слободније схватао појам књижевне критике и да није инсистирао на њеном стриктном припадању подручју науке о књижевности.

Петар Џаџић у тексту из 1960. године, „Критика јуче и данас” (1996а: 9-19) не пориче субјективност критике, али са друге стране увиђа њену повезаност са профилом времена у којем она настаје. Упућује на то да је идеал књижевне критке био да пронађе један универзални образац лепоте, али уметност нашег времена (и било којег другог, прим. аут.) не познаје тако нешто. Уместо једноставног оцењивања, задатак књижевне критике јесте да се бави пажљивим тумачењем вредности. Критика треба да се занима за естетску реалност дела, а да притом нема у виду само један естетски или етички идеал. Са друге стране, то не значи да критка може престати да буде суђење, али је јасан Џаџићев нагативан став према текућој критици која је само вредновање и егзегеза без закључне анализе. Међутим, проблем нове критике је што жели да описује а не да оцењује, док само оцењивање, оно најузбудљиве и најосетљивије, препушта новинарима. Вредност критике треба тумачити другачије у односу на вредност књижевности. Треба је снажније контекстуализовати јер она увек говори из неког одређеног временског тренутка. Иако се врло негативно осврнуо на новинску критику опредељену само ка чину суђења вредности и сматрао да критика мора имати обзира према научном начину мишљења, она и за Џаџића није наука, већ делатност човековог духа која је ангажована књижевним делом. Оно што је важно упркос постављању критике ван области науке, јесте да се њен дух не сме супротставити духу науке. Тако Џаџићево виђење књижевне критике опет ову стваралачку активност посматра тако да она припада и једном и другом пољу - и књижевности и науци.

Џаџић се, како смо поменули, посебно бавио личношћу самих критичара и њиховим професионалним профилом. За њега је критичар егзистенција недовршена и отворена, па зато говори о критичаревом неригидном ја (1996б: 9-61) ${ }^{17}$. Критичар мора имати сензибилитет и осећај за нове вредности, али и способност непосредног изрицања суда и вредновања када то нико раније урадио није. Џаџић није претерано наклоњен методологији, јер сматра да свака метода поред тога што даје, прилично и ограничава. За критику је зато боље да се користи тоталном методом, односно да се залаже за методолошки плурализам. С друге стране, сама

могу лако да подлегну захтевима и мерилима теорија. Будући да и сами пишу критику, односно да се баве науком, они своју књижевност могу подредити и интерпретативним могућностима у оквиру „пожељних” методолошких путева.

${ }^{17}$ Текст „Човек са теразијама или неригидно критичарево ја” објављен је 1975. године. 
природа науке о књижевности је таква да не испуњава научне принципе као друге науке. Не верује превише ни у методе критичарског суђења, ни у књижевне групације са заједничком естетичком идејом и залаже се за аутономију критике која не би требало да буде изманипулисана. Отуда је критика индивидулни чин који много зависи од способности самог критичара. Тежња за „продужењем ритма другог” у себи је иницијални чин критике, а критичар је увек спреман за авантуру потпуне идентификације али и потпуне критичарске дистанце. Осим тога, Џаџић скреће пажњу на то да критика не може бити трансисторична и да остаје у дослуху са временом у којем је настала, са датом традицијом и културом. Посебно је сматрао да треба одвојити текућу критику од науке о књижевности, образлажући своју тврдњу тиме да критика подразумева оцену коју наука о књижевности не мора да подразумева. Отуда говори о новој критици која се одриче судијских претензија и постаје партнер књижевном делу, користећи домете свих хуманистичких проучавања. На плану тумачења, то је иманентна анализа која се бави самим текстом и од њега се не удаљава.

Драган М. Јеремић у тексту „Критичар и естетски идеал” (1965) издваја пет типова критике: критику као врсту књижевног изражавања, критику као педагогију укуса, критику као припремање теорије књижевности, критику као руководство књижевног пута, критику као припрему историје књижевности. И сходно томе пет врста књижевних критичара: уметника, педагога, вођу књижевних група, историчар и теоретичара књижевности. На почетку је одређује као књижевну врсту (род) коју је тешко дефинисати, али која свакако представља манифестацију књижевности односно уметности. Сматрао је да су наши критичари највише импресионисти, а најмање естетичари, будући да естетичар утврђује законе свега што постоји у уметности, а критичар усваја један естетски идеал и бори се за његово остварење.

Уочавамо да се и код нама временски ближих критичара, који су се и сами бавили писањем различитих форми књижевнокритичког дискурса, подручје књижевне критике и даље смешта и уобласт књижевности и у област науке, а да то не мора увек бити условљено припадношћу текста академској или дневној критици. Појављује се и гранична зона између књижевности и науке као златни пресек и место где књижевна критика најприродније обитава, што се дало уочити и код филолога с почетка 20. века.

\section{4. Ка данашњем поимању књижевне критике}

Где је књижевна критика данас на крају друге деценије 21. века и какав је њен положај у односу на науку и књижевност? За Тихомира Брајовића она је самосвесно читање, док је критичар, аналогно томе, 
самосвесни читалац - „онај који литератури приступа што је непосредније могуће, али са упорним и непопустљивим обазирањем на познавање теорија, метода и техника разумевања и тумачења" (2009: 7). Критичар мање или више ужива у читању, по угледу на каквог идеалног, „наивног” и пријемчивог читаоца, али је у исто време и ауторефлексиван, обазрив према властитим наклоностима и ненаклоностима, критичан и према једнима и према другима.

У том смислу, Брајовић говори о критичару као двоструком читаоцу. Поред тога што му је примарни задатак да чита друге, он чита и самог себе, поседујући (ауто)дијалошку пасију и потребу за (само)разговором поводом књижевних дела. Као трајно отворена интерпретација и самоинтерпретација, критика постаје облик и жанр, који је и те како примерен и потребан овом времену свеопштих преиспитивања и превредновања (BRAJOVIĆ 2009: 8). Књижевна критика има и свој етос и свој ерос, а налази се између објективности и емпатијске субјективности.

Новица Петковић је пак јасно ставља у границе науке, подразумевајући ослањање на одређену методологију: „Њен је основни задатак тумачење поезије, као и њено вредновање које из тумачења произилази. Стога се она мора наслонити или, боље речено, мора подразумевати извесну теорију о природи поезије и њеном месту у култури.” $(2008: 383)^{18}$. О садашњем статусу критике и о њеној будућности помало циничним тоном говори и Александар Јерков, песимистично јој наговештавајући издисај (2013: 411). Сматра да критике нема и да је неће бити, али и да је једва било, те да је имала епохалан историјски значај једино у доба модерне (2013: 430). Критички плурализам или плуралистичка критика је једно од могућих одређења српске књижевне критике у другој половини 20. века, а као најважније типове критике издваја књижевноисторијску, књижевнотеоријску, културолошку и импресионистичку (JERKOV 2013: 458, 459).

Почетак 21. века пред критичаре оставља исте дилеме о природи књижевне критике као и почетак 20. века, с тим што је ауторитет и критике и критичара данас далеко мањи. Маргинални статус који међу научним радовима добијају критички текстови писани од стране научника филолога ${ }^{19}$, довео је до тога да се критиком баве и они аутори који не припадају научној јавности, те да њихови критички осврти чак узимају првенствно по бројности у часописној критици. Упркос постојању различитих форми хетерогеног књижевнокритичког дискурса о којем је гово-

\footnotetext{
${ }^{18}$ Петковићев став односи се на критику поезије, али се лако може применити на књижевну критику било којег књижевног жанра.

19 Имамо у виду и непрепознавање књижевне критике приликом квантитативне валоризације резултата научног рада истраживача.
} 
рио Пантић (1984) долазимо до закљука да је позиционирање књижевне критике и њен однос према науци и уметности остајао неразјашњен захваљујући и оваквим видовима критике, што примећујемо током читавог овде наведеног временског периода. Отуда проблематика разврставања различитих облика критичких осврта у оно што припада или не припада науци истрајава и данас. Афирмативнији став према критици унутар научне заједнице могао би допринети и њеном квалитету, подробнијим интерпретацијама и квалитетнијим освртима.

\section{Цитирана литература}

BOGDANOVIĆ 1979: BOGDANOVIĆ, Milan. Kritički radovi Milana Bogdanovića. Novi Sad: Matica srpska - Beograd: Institut za književnost i umetnost, 1979. [orig.] БОГДАНОВИЋ, Милан. Критички радови Милана Богдановића. Нови Сад: Матица српска - Београд: Институт за књижевност и уметност, 1979.

BRAJOVIĆ 2009: BRAJOVIĆ, Tihomir. Kratka istorija preobilja: kritički bedeker kroz savremenu srpsku poeziju i prozu. Zrenjanin: Agora, 2009. [orig.] БРАJOВИЋ, Тихомир. Кратка историја преобиља: критички бедекер кроз савремену српску поезију и прозу. Зрењанин: Агора, 2009.

DŽADŽIĆ 1996a: DŽADŽIĆ, Petar. Iz dana u dan I. Beograd: Zavod za udžbenike i nastavna sredstva, 1996. [orig.] ЏАЏИЋ, Петар. Из дана у дан I. Београд: Завод за уџбенике и наставна средства, 1996.

DŽADŽIĆ 1996б: DŽADŽIĆ, Petar. Iz dana u dan II. Beograd: Zavod za udžbenike i nastavna sredstva, 1996. [orig.] ЏАЏИЋ, Петар. Из дана у дан II. Београд: Завод за уџбенике и наставна средства, 1996.

IGLTON 1987: EAGLETON, Terry. Književna teorija. Prev. Mia Pervan-Plavec. Zagreb: Liber, 1987.

JEREMIĆ 1965: JEREMIĆ, Dragan. Kritičar i estetski ideal. Titograd: Grafički zavod, 1965.

JERKOV 2013: JERKOV, Aleksandar. „Šta bi srpska kritika bila?” U: M. Radulović (ur.) Srpska književna kritika druge polovine XX veka: tipološka proučavanja. Beograd: Institut za književnost i umetnost, 2013: 413-434. [orig.] Јерков, Александар. „Шта би српска критика била?” У: М. Радуловић (ур.). Срnска књижевна критика друге половине ХХ века: типолошка проучавања. Београд: Институт за књижевност и уметност, 2013: 413-434.

KOMPANJON 2001: KOMPANJON, Antoan. Demon teorije. Prev. M. Kozić, V. Kapor, B. Rakić. Novi Sad: Svetovi, 2001. [orig.] КОМПАЮОН, Антоан. Демон теорије. Прев. М. Козић, В. Капор, Б. Ракић. Нови Сад: Светови, 2001. 
LAZAREVIĆ 1975: LAZAREVIĆ, Branko. Kritički radovi Branka Lazarevića. Novi Sad: Matica srpska - Beograd: Institut za književnost i umetnost, 1975. [orig.] ЛАЗАРЕВИЋ, Бранко. Критички радови Бранка Лазаревића. Нови Сад: Матица српска - Београд: Институт за књижевност и уметност, 1975.

MIŠIĆ 1965: MIŠIĆ, Zoran. Kritika pesničkog iskustva. Beograd: SKZ, 1965. [ориг.] МИШИЋ, Зоран. Критика песничког искуства. Београд: СКЗ, 1965.

MUKARŽOVSKI 1987: MUKARŽOVSKI, Jan. Struktura, funkcija, znak, vrednost: ogledi iz estetike i poetike. Beograd: Nolit, 1987.

NEDIĆ 1977: NEDIĆ, Ljubomir. Studije i kritike Ljubomira Nedića. Novi Sad: Matica srpska - Beograd: Institut za književnost i umetnost, 1977. [orig.] HEДИЋ, Љубомир. Студије и критике Љубомира Недића. Нови Сад: Матица српска - Београд: Институт за књижевност и уметност, 1977.

PALAVESTRA 2008: PALAVESTRA, Predrag. Istorija srpske književne kritike: 1768-2007. Tom 1. Novi Sad: Matica srpska, 2008. [orig.] ПАЛАВЕСТРА, Предраг. Историја српске књижевне критике: 1768-2007. Том 1. Нови Сад: Матица српска, 2008.

PANTIĆ 1984: PANTIĆ, Mihajlo. „O nekim odlikama dnevne kritike”. U: P. Palavestra (ur.). Prilozi za istoriju srpske književne kritike. Beograd: Institut za književnost i umetnost - Novi Sad: Matica srpska, 1984: 131-141. [orig.] ПАНТИЋ, Михајло. „О неким одликама дневне критике”. У: П. Палавестра (ур.). Прилози за историју српске књижевне критике. Београд: Институт за књижевност и уметност - Нови Сад:Матица српска, 1984: 131-141.

PERIŠIĆ 2013: PERIŠIĆ, Igor. „Estetička kritka i književna teorija: Prilog za tipologizaciju srpske književne kritike". U: M. Radulović(ur.). Srpska književna kritika druge polovine XX veka: tipološka proučavanja. Beograd: Institut za književnost i umetnost, 2013: 165-182. [orig.] ПЕРИШИЋ, Игор. „Естетичка критка и књижевна теорија: Прилог за типологизацију српске књижевне критике". У: М. Радуловић (ур.). Српска књижевна критика друге половине XX века: типолошка проучавањ $а$. Београд: Институт за књижевност и уметност, 2013: 165-182.

PERIŠIĆ 2014: PERIŠIĆ, Igor. Kritika i metakritika: prilozi za teoriju $i$ istoriju srpske književne kritike. Beograd: Institut za književnost i umetnost, 2014. [orig.] ПЕРИШИЋ, Игор. Критика и метакритика: прилози за теорију и историју српске кьижевне критике. Београд: Инститит за књижевност и уметност, 2014.

PETKOVIĆ 2008: PETKOVIĆ, Novica. „Poezija i kritika: Uvod u tumačenje lirske poezije". U: O. Radulović (ur.). Tumačenje književnog dela i metodika nastave. Deo 1. Novi Sad: Filozofski fakultet, 2008: 383-419. ПЕТКОВИЋ, Новица. „Поезија и критика: Увод у тумачење лирске поезије”. У: О. Радуловић (ур.). Тумачење књижевног дела и методика наставе. Део 1. Нови Сад: Филозофски факултет, 2008: 383-419. 
PETROVIĆ 2009: PETROVIĆ, Svetozar. Nauka o književnosti: izabrani spisi. Beograd: službeni glasnik, 2009.

POPOVIĆ 1977: POPOVIĆ, Bogdan. Kritički radovi Bogdana Popovića. Novi Sad: Matica srpska - Beograd: Institut za književnost i umetnost, 1977. [orig.] ПОПОВИЋ, Богдан. Критички радови Богдана Поповића. Нови Сад: Матица српска - Београд: Институт за књижевност и уметност, 1977.

POPOVIĆ 1979: POPOVIĆ, Pavle. Pavle Popović i istorijska kritika: izabrani kritički radovi Pavla Popovića. Novi Sad: Matica srpska - Beograd: Institut za književnost i umetnost, 1979. [orig.] ПОПОВИЋ, Павле. Павле Поповић и историјска критика: изабрани критички радови Павла Поповића. Нови Сад: Матица српска - Београд: Институт за књижевност и уметност, 1979.

RADULOVIĆ 2013: RADULOVIĆ, Milan. „Sistematizacija srpske književne kritike". U: M. Radulović (ur.). Srpska književna kritika druge polovine XX veka: tipološka proučavanja. Beograd: Institut za književnost i umetnost, 2013: 435-469. [orig.] РАДУЛОВИЋ, Милан. „Систематизација српске књижевне критике". У: М. Радуловић (ур.). Српска књижевна критика друге половине XX века: типолошка проучаваға. Београд: Институт за књижевност и уметност, 2013: 435-469.

SEKULIĆ 1977: SEKULIĆ, Isidora. Kritički radovi Isidore Sekulić. Novi Sad: Matica srpska - Beograd: Institut za književnost i umetnost, 1977. [orig.] CEКУЛИЋ, Исидора. Критички радови Исидоре Секулић. Нови Сад: Матица српска - Београд: Институт за књижевност и уметност, 1977.

SKERLIĆ 2000: SKERLIĆ, Jovan. Pisci i knjige II. Beograd: Zavod za udžbenike i nastavna sredstva, 2000. [orig.] СКЕРЛИЋ, Јован. Писци и књиге II. Београд: Завод за уџбенике и наставна средства, 2000.

Jelena S. Mladenović

\section{A REVIEW OF THE STATES ABOUT THE NATURE OF LITERARY CRITICISM IN THE SERBIAN PHILOLOGY}

The problematic status of literary criticism within the philology has been present almost from the moment of creating this particular philology field that deals with an interpretation and evaluation of literary works. We have conducted this research in order to systematize just one part of the theoretical views on the nature of literary criticism, which we find in the Serbian philology during the $20^{\text {th }}$ century. Reflections on the topic of literary criticism, as well as theoretical discourse in different essays, will be considered through metacritical attitudes presented in the canonical texts of the classics in Serbian literary criticism Ljubomir Nedić, Bogdan Popović and Jovan Skerlić, and then with a number 
of philologists during the $20^{\text {th }}$ century - Branko Lazarević, Isidora Sekulić, Milan Bogdanović, Zoran Mišić, Dragan M. Jeremić, Petar Džadžić, Predrag Palavestra and others. The literary criticism needs a constant re-evaluation in order to justify its belonging to the field of philology. A rethinking of the relationship between theory and criticism will lead us to the question where is literary criticism today.

Keywords: literary criticism, metacritics, academic criticism, daily criticism, Serbian philology 